\title{
Ground Cover Impacts on Nitrogen Export from Manured Riparian Pasture
}

\author{
David M. Butler,* Noah N. Ranells, Dorcas H. Franklin, Matthew H. Poore, and James T. Green, Jr.
}

\begin{abstract}
Maintaining ground cover of forages may reduce the export of nitrogen $(\mathrm{N})$ from pastures. The objective of this work was to determine the effect of ground cover on $\mathbf{N}$ export from pastured riparian areas receiving simulated rainfall. Plots were established on two adjacent sites in the North Carolina Piedmont: one of $10 \%$ slope with Appling sandy loam soils and a second of $20 \%$ slope with Wedowee sandy loam soils. Both sites had existing mixed tall fescue (Festuca arundinacea Schreb.)-dallisgrass (Paspalum dilatatum Poir.) vegetation. Forage stands were modified to represent a range of ground cover levels: 0 , 45,70 , and $95 \%$ (bare ground, low, medium, and high cover, respectively), and amended with beef steer (Bos taurus) feces and urine $\left(\sim 200 \mathrm{~kg} \mathrm{~N} \mathrm{ha}^{-1}\right)$. For all rain events combined, mean nitrate $\mathrm{N}$ export was greatest from bare ground and was reduced by $34 \%$ at low cover, which did not differ from high cover. Mean ammonium $\mathbf{N}$ export was slightly elevated $\left(\sim 1.37 \mathrm{~kg} \mathrm{~N} \mathrm{ha}^{-1}\right)$ in months when manures were applied and negligible $\left(<0.02 \mathrm{~kg} \mathrm{~N} \mathrm{ha}^{-1}\right)$ in all other months. For all rain events combined, mean export of total $N$ was greatest from bare ground and was reduced by at least $85 \%$ at all other cover levels. Whereas site did not impact $\mathrm{N}$ export, results indicated that cover and time of rainfall following manure deposition are important determinants of the impact of riparian grazing.
\end{abstract}

$\mathrm{T}$ $\mathrm{HE}$ cycling of nitrogen $(\mathrm{N})$ in grazing systems has been the focus of numerous studies (Haynes and Williams, 1993). Grazing cattle return approximately $80 \%$ of ingested $\mathrm{N}$ to the pasture as feces and urine patches, creating microsites of high $\mathrm{N}$ concentration (Kohn et al., 2005). Runoff, leaching, and gaseous losses of $\mathrm{N}$ from these areas can lead to environmental degradation and reduced pasture productivity. When feces and urine are deposited in riparian areas, proximity to surface waters creates an increased environmental hazard from transported N. Consequently, grazing cattle (Bos spp.) can be a source for eutrophication in the eastern USA when runoff and leachate becomes contaminated with $\mathrm{N}$ from urine and feces and transport it to surface waters (White et al., 1980; Carpenter et al., 1998).

Eutrophication can initiate algal blooms, which, after dying, reduce dissolved oxygen levels, kill fish, reduce biodiversity, and otherwise reduce the suitability of waters for use by humans and wildlife. In response to major fish kills following eutrophication in the Neuse and Tar-Pamlico rivers, the North Carolina state legislature enacted regulations for all land uses as part of a com-

D.M. Butler, N.N. Ranells, and J.T. Green, Jr., Dep. of Crop Science, North Carolina State Univ., Box 7620, Raleigh, NC 27695. D.H. Franklin, USDA-ARS, J. Phil Campbell Sr. Natural Resource Conservation Center, 1420 Experiment Station Rd., Watkinsville, GA, 30677. M.H. Poore, Dep. of Animal Science, North Carolina State Univ., Box 7621, Raleigh, NC, 27695. Received 24 Feb. 2006. *Corresponding author (dmbutler@uga.edu).

Published in J. Environ. Qual. 36:155-162 (2007).

Technical Reports: Surface Water Quality

doi:10.2134/jeq2006.0082

(c) ASA, CSSA, SSSA

677 S. Segoe Rd., Madison, WI 53711 USA prehensive effort to improve water quality. For agricultural land uses, there were assessment tools for row crop contributions, but the impact of grazing livestock on $\mathrm{N}$ export to North Carolina surface waters has not been well quantified. In 2002, an estimated 705000 ha, or $\sim 20 \%$, of North Carolina agricultural land was used for grazing (USDA, 2002), which makes the impact of grazing on water quality critically important.

Areas in and near the riparian zone are often grazed because they are typically unsuitable for row crop production due to topography and seasonal flooding, but can have relatively high forage productivity because of favorable moisture conditions during drier periods of the year. However, poor grazing management can lead to variable stand density and forage ground cover (Alderfer and Robinson, 1947). Poor stands can negatively influence infiltration, runoff, erosion, and sediment deposition and limit the ecosystem services provided by the riparian area (McGinty et al., 1979; Loch, 2000). However, while there are data relating to runoff volume and nutrient export from grasslands in the Southeast, there are few data that report the level of ground cover necessary to protect water quality when livestock graze in or near riparian areas.

Controlling runoff volume can help reduce the export of $\mathrm{N}$ from pastures regardless of the actual $\mathrm{N}$ concentration in the runoff. Several studies in diverse environments have suggested threshold levels of 70 to $75 \%$ ground cover, below which significantly greater runoff volume can occur (Lang, 1979; Costin, 1980; Mwendera and Saleem, 1997). Lang (1979) suggested that when ground cover estimated by the point or area quadrat method dropped below $75 \%$, bare areas began to connect with each other, increasing runoff rates and decreasing infiltration. Similarly, Costin (1980) reported that ground cover values $<70 \%$, also estimated using the quadrat method, resulted in significantly greater runoff rate than at ground cover levels $>70 \%$.

Slightly different results were reported by Dadkhah and Gifford (1980) in a Utah study of infiltration rate and sediment production. Cover was established by uprooting vegetation in randomly selected squares of a grid. There was no difference in infiltration rate from plots at either 50 or $80 \%$ ground cover. The researchers suggested that ground cover levels of $50 \%$ or greater may be sufficient for adequate watershed protection.

Few studies, however, have examined the impact of ground cover to $\mathrm{N}$ export from pastures. In New Zealand, Elliott and Carlson (2004) examined the impact of sheep grazing perennial ryegrass (Lolium perenne L.)-white clover (Trifolium repens L.) pasture on nutrient export and reported that runoff total Kjeldahl nitrogen (TKN)

Abbreviations: $\mathrm{NH}_{4}-\mathrm{N}$, ammonium-nitrogen; $\mathrm{NO}_{3}-\mathrm{N}$, nitrate-nitrogen; TKN, total Kjeldahl nitrogen; TN, total nitrogen. 
concentrations increased linearly with the percentage of bare ground when runoff occurred immediately after grazing. Concentrations of TKN in runoff increased more than fourfold as the percentage of bare ground, measured using the cross points of a grid, increased from 1 to $11 \%$. However, slopes in this study were rather steep, ranging from 20 to $35 \%$, perhaps limiting extrapolation of results to less steep topography.

Though not directly examining the impact of cover, Edwards et al. (2000a) examined the effects of tall fescue (Festuca arundinacea Schreb.) clipping height on $\mathrm{N}$ export following application of feces and urine. The researchers reported that higher clipping heights were associated with the greatest flow-weighted nitrate $\mathrm{N}$ $\left(\mathrm{NO}_{3}-\mathrm{N}\right)$ and TKN concentrations during $30 \mathrm{~min}$ of runoff. The authors suggested that the slower growth of the forages managed at greater heights resulted in less $\mathrm{N}$ uptake, leaving more $\mathrm{N}$ available for transport in runoff. The authors also reported that there was a lessened interaction of runoff with the soil surface at higher clipping heights.

As data are lacking on the impact of ground cover to export of $\mathrm{N}$ from pastures, this study evaluated the impact of ground cover in riparian pasture plots to the export of $\mathrm{N}$ in runoff on two adjacent sites and the concentration of $\mathrm{N}$ in soil water extracts on one site. In this experiment, the impacts of bare ground and low, medium, and high ground cover levels on the export of $\mathrm{NO}_{3}-\mathrm{N}$, ammonium $\mathrm{N}\left(\mathrm{NH}_{4}-\mathrm{N}\right)$, and total $\mathrm{N}(\mathrm{TN})$ were examined.

\section{MATERIALS AND METHODS Site Description}

In February 2003, research plots were established on existing mixed tall fescue-dallisgrass (Paspalum dilatatum Poir.) pasture which had been established for over $20 \mathrm{yr}$ at North Carolina State University's Lake Wheeler Road Field Laboratory in Raleigh, NC $\left(35^{\circ} 43^{\prime} \mathrm{N}\right.$; 78 $41^{\prime} \mathrm{W}$; elevation $=$ $100 \mathrm{~m})$. Randomized complete block experiments were established on two slopes ( $10 \%$ and $\sim 20 \%$ ) between 5 and $10 \mathrm{~m}$ landward from a stream. The soil on the $10 \%$ slope site was an Appling sandy loam (fine, kaolinitic, thermic Typic Kanhapludult) and the soil on the $20 \%$ slope site was a Wedowee sandy loam (fine, kaolinitic, thermic Typic Kanhapludult). The most notable difference between the soils was the presence of approximately $10 \%$ coarse gravel in the $10-\mathrm{cm}$ Ap horizon on the $20 \%$ slope site, whereas the presence of gravel was negligible in upper horizons on the $10 \%$ slope site. Soil cores were examined before plot establishment to ensure consistency of soils within block and within slope.

Experimental plots were 0.75 by $2.0 \mathrm{~m}$ and delineated with galvanized sheet metal flashing $23 \mathrm{~cm}$ wide, placed into the soil to a depth of $18 \mathrm{~cm}$ to isolate the surface hydrology of the plots. A runoff collection gutter was placed at the downslope edge $(0.75 \mathrm{~m})$ of each plot.

\section{Cover Treatments}

Upon initiation of this study, four ground cover treatments were established with four replications of each treatment, for a total of sixteen plots on each site. Ground cover levels were created by establishing $100 \%$ bare soil area with $0 \%$ ground cover, $55 \%$ bare soil area with $45 \%$ ground cover, $30 \%$ bare soil area with $70 \%$ ground cover, and not altering full $(95 \%)$ vegetative cover plots. Bare soil areas were created using a 5 by $10 \mathrm{~cm}$ rectangular grid and a small hand flame to quickly heat and kill statistically random blocks of vegetative cover. The random blocks created a pattern of varying sizes of bare soil areas as selected blocks connected with each other. After using the flame, herbage residue was raked from the plots. During the subsequent 3 to $4 \mathrm{wk}$, any remaining residue was removed during natural rainfall events. Small rectangles of black plastic were placed on the plots in the same random grid pattern to maintain desired ground cover between rain events once the treatments of feces and urine were applied to the plots. Plastic was removed before simulated rain events.

The $0 \%$ ground cover treatment was established in each replication to simulate a compacted, cattle heavy use or 'lounging' area. Simulated lounging treatments were established by using black plastic to cover the whole plot and kill all vegetation by solarization. A steel compaction device with an impact surface area of $100 \mathrm{~cm}^{2}$ was used to simulate cattle hoof compaction over the entire $0 \%$ cover plot, using methods described by Clary (1995). Simulated lounging plots were compacted before the first simulated rain event in April and again before the first fall rain event in September.

To standardize canopy height at each rain event, plots were harvested to a $10-\mathrm{cm}$ stubble height before each rainfall simulation, as well as in July 2003 for plot maintenance. The forage samples from each harvest were dried $\left(65^{\circ} \mathrm{C}\right)$, weighed, and then analyzed by the North Carolina Dep. of Agriculture and Consumer Services (NCDA\&CS) Agronomic Division for TN by combustion as described in AOAC International method 990.03 (Cunniff, 1995). Percentage canopy cover was determined using the line transect method with 40 points after the vegetation was harvested to $10 \mathrm{~cm}$ and immediately before the rainfall simulations (Laflen et al., 1981; Table 1).

\section{Rainfall Simulations}

Before each simulated rainfall, three soil cores (1.75-cm i.d.) extracted from a 0 - to $5-\mathrm{cm}$ depth were obtained from each plot. In each plot, soil cores were combined into a composite sample, which was divided into two subsamples. One sample was air-dried and ground, while the second was placed in a soil tin and dried at $105^{\circ} \mathrm{C}$ for $24 \mathrm{~h}$ to determine gravimetric soil moisture content. The air-dried and ground sample was extracted by shaking 10 -g soil samples in $25 \mathrm{~mL}$ of $1 M$ potassium chloride $(\mathrm{KCl})$ solution. The resulting filtrate was analyzed using the salicylate-hypochlorite method for $\mathrm{NH}_{4}-\mathrm{N}$ (Crooke and Simpson, 1971) and the Griess-Ilosvay method (Keeney and Nelson, 1982) for $\mathrm{NO}_{3}-\mathrm{N}$ and nitrite- $\mathrm{N}\left(\mathrm{NO}_{2}-\mathrm{N}\right)$ following reduction of $\mathrm{NO}_{3}{ }^{-}$to $\mathrm{NO}_{2}^{-}$with a Cd column. Concentrations of $\mathrm{NH}_{4}-\mathrm{N}, \mathrm{NO}_{3}-\mathrm{N}$, and $\mathrm{NO}_{2}-\mathrm{N}$ were then summed to obtain a measure of soil inorganic $\mathrm{N}$. Total soil $\mathrm{N}$ was determined using a PerkinElmer $2400 \mathrm{CHN}$ Elemental Analyzer (PerkinElmer, Wellesly, NJ).

Table 1. Mean measured canopy cover at each cover level, averaged across sites.

\begin{tabular}{|c|c|c|c|c|c|}
\hline \multirow[b]{3}{*}{ Cover } & \multicolumn{5}{|c|}{ Canopy cover } \\
\hline & \multicolumn{5}{|c|}{ Rain event } \\
\hline & Base & May & June & Sept. & Oct. \\
\hline & & & $-\%$ & 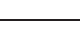 & - \\
\hline Bare & $\mathbf{0 a} \dagger$ & $\mathbf{0 a}$ & 0a & $\mathbf{0 a}$ & 0a \\
\hline Low & $63 b$ & $65 b$ & $78 b$ & $75 b$ & 78b \\
\hline Medium & $76 c$ & $78 \mathrm{c}$ & $83 c$ & $80 \mathrm{c}$ & $80 \mathrm{~b}$ \\
\hline High & 94d & 95d & 98d & 92d & 83b \\
\hline
\end{tabular}

$\dagger$ Means in the same column followed by the same letter are not significantly different $(P>0.05)$. 
Three rainfall simulators (Tlaloc 3000, Joern's, West Lafayette, IN) were used to simulate rainfall at an intensity of $70 \mathrm{~mm} \mathrm{~h}^{-1}$ for a 1-h duration. This is just above a 10-yr, 1-h rain event of $\sim 65 \mathrm{~mm} \mathrm{~h}^{-1}$ for Raleigh, NC, whereas a $25-\mathrm{yr}$, 1-h rain event for Raleigh is $\sim 85 \mathrm{~mm} \mathrm{~h}^{-1}$ (Hershfield, 1961). Simulators were randomly assigned to blocks at each rain event, and the same simulator was used on all plots within a block. Each simulator rained on two plots simultaneously. In April 2003, an initial rainfall simulation was conducted to determine baseline runoff conditions from each plot before application of feces and urine in May 2003. Deionized water was used as source water for the rainfall simulators. Great care was taken to ensure equal volume and distribution of rainfall from each simulator each time used. Simulators were calibrated by measuring volume and distribution of rain and adjusting the pressure valve at each simulator accordingly before moving simulators onto plots. Rain gauges were placed in plots to verify rainfall rate for each rain event.

Time was recorded as runoff began to drip from the gutter and the initial $125 \mathrm{~mL}$ of runoff was collected. When steady flow began, time was again recorded and a timer started so that runoff could be sampled beginning at 5, 10, 15, 20, 25, and 30 min after initiation of steady runoff flow. At each sampling time interval, $500 \mathrm{~mL}$ of runoff was obtained. Runoff between samplings was collected into large containers and weighed every $5 \mathrm{~min}$ after the initiation of steady runoff state until 30 min of runoff had occurred from each plot. The same methods of rainfall application and runoff collection were used for all rainfall simulations.

\section{Feces and Urine Application}

Feces and urine were applied in late May to plots immediately before rainfall simulations at a rate that approximated $10 \%$ of the average daily output for mature cattle (Kohn et al., 2005). This equated to a 2.4-kg deposit of feces (at $850 \mathrm{~g} \mathrm{H}_{2} \mathrm{O}$ $\mathrm{kg}^{-1}$ wet manure) applied on a $550-\mathrm{cm}^{2}$ area and a $1-\mathrm{L}$ urine deposit applied over an equal area. The center of the fecal deposit was placed $30 \mathrm{~cm}$ from the top of the plot and centered between the plot sides. The 1-L urine deposit was placed directly adjacent and down slope of the fecal deposit. The two applications to each plot are representative of a stocking rate of $\sim 4$ cows ha $\mathrm{hr}^{-1} \mathrm{yr}^{-1}$ assuming even distribution of feces and urine within a pasture. The rate of $\mathrm{N}$ application in feces and urine was $\sim 100 \mathrm{~kg} \mathrm{~N} \mathrm{ha}^{-1}$, at both the May and September rain events (Table 2). Of this amount, $\sim 70 \mathrm{~kg} \mathrm{~N} \mathrm{ha}^{-1}$ was applied in urine, which, because in a liquid phase, was very susceptible to runoff or leaching. The amount of inorganic $\mathrm{N}$ extracted by water from the feces was $0.416 \mathrm{~kg} \mathrm{~N} \mathrm{ha}^{-1}$ in May and $0.494 \mathrm{~kg}$ $\mathrm{N} \mathrm{ha}{ }^{-1}$ in September.

The feces and urine were collected from four beef steers fed switchgrass (Panicum virgatum L.) and gamagrass [Tripsacum dactyloides (L.) L.] hay as part of an unrelated study. Feces were mixed and formed into $2.4-\mathrm{kg}$ portions $(\sim 0.33 \mathrm{~kg}$ dry

Table 2. Nitrogen (N) application rate in cattle feces and urine.

\begin{tabular}{llcc}
\hline Dates of application & \multicolumn{1}{c}{$\begin{array}{c}\text { Manure } \\
\text { component }\end{array}$} & Total N & Water-extractable N \\
\cline { 3 - 4 } 21, 22, 27, 28 May & feces & 31.4 & $\mathbf{k g ~ N ~ h a ~}$ \\
& urine & 73.3 & $\mathbf{0 . 4 1 6}$ \\
9, 10, 11 Sept. & feces & $\mathbf{2 6 . 0}$ & $\mathbf{0 . 4 9 4}$ \\
& urine & $\mathbf{7 3 . 3}$ & N/A \\
& feces total & $\mathbf{5 7 . 4}$ & $\mathbf{0 . 9 1 0}$ \\
& urine total & $\mathbf{1 4 6 . 6}$ & N/A \\
& total applied & $\mathbf{2 0 4 . 0}$ & N/A \\
\hline
\end{tabular}

$\dagger \mathbf{N} / A$, not available. matter) 25 by $14 \mathrm{~cm}$ wide and $6 \mathrm{~cm}$ thick before being frozen until thawed for plot application. Urine was collected in buckets placed under the steers while in metabolism crates. The collected urine was mixed, adjusted to a $\mathrm{pH}$ level of 6 with $\mathrm{HCl}$ to prevent precipitation of solids and $\mathrm{N}$ losses to ammonia $\left(\mathrm{NH}_{3}\right)$, and then frozen until thawed for plot application. Feed grade urea was added to adjust urine to $1 \% \mathrm{~N}$ content directly before application to plots. Fecal samples were analyzed by the NCDA\&CS Agronomic Division for TN by the combustion method, as described in AOAC International method 990.03 (Cunniff, 1995). Urine-N was determined by Kjeldahl digestion by methods described in USEPA method 351.2 (USEPA, 1993). Water-soluble $\mathrm{N}$ was determined using methods described by Kleinman et al. (2002) for water-extractable phosphorus in manures. Fresh manure samples (1-g dry wt. equivalent) were shaken with $200 \mathrm{~mL}$ of deionized water for $1 \mathrm{~h}$, centrifuged, filtered $(0.45 \mu \mathrm{m})$, and analyzed for $\mathrm{NH}_{4}-\mathrm{N}$, $\mathrm{NO}_{3}-\mathrm{N}$, and $\mathrm{NO}_{2}-\mathrm{N}$ by the same methods used to determine soil inorganic $\mathrm{N}$. The resulting values were summed to obtain a measure of soluble N, which would be most available for immediate transport in runoff during rain events.

Following rainfall simulations in May 2003, hoop structures were used to shield plots from direct rainfall during natural rainfall events to prevent runoff. Rainfall simulations were again conducted 9-11 June 2003 to determine runoff constituents from plots, but without additional application of feces and urine. Plots were again treated with feces and urine before rainfall simulations on 9-11 Sept. 2003, which were followed by rainfall simulations on $6-8$ Oct. 2003 without an additional plot treatment of feces and urine. Feces and urine application in September was on the same location on the plot, but the recognizable fecal material remaining from the spring was manually removed from the plot, weighed, and a 30-g sample retained for $\mathrm{TN}$ determination. The remaining fecal mass was manually broken up into pieces of similar size $(<5 \mathrm{~cm})$ and distributed in the $50-$ by $50-\mathrm{cm}$ area surrounding the original fecal deposit immediately before the new application of feces and urine in September.

\section{Lysimeter Installation}

Before fall rain events in September, round bottom ceramic suction cup lysimeters attached to a $90-\mathrm{cm}$ length of polyvinyl chloride piping were installed under the plots on the site of $10 \%$ slope. Ceramic suction cups were $7.0 \mathrm{~cm}$ long and $2.2 \mathrm{~cm}$ in diameter with a $2.5-\mu \mathrm{m}$ pore size and a 1-bar, high flow air entry value. To prepare for installation, an auger was used to drill a hole from outside the plot area at a $40^{\circ}$ angle, so that the suction cup of the lysimeter was $\sim 80 \mathrm{~cm}$ below the center of the feces and urine application area. Soil removed by the auger was mixed with deionized water to form a thick soil slurry, which was poured into the hole before insertion of the lysimeter. Samples were collected by vacuum at September and October rain events immediately before and after rainfall simulations, as well as 24 -h after the rain event.

\section{Sample Collection and Analysis}

Runoff sample vials were placed in ice and in the dark until transported to the lab. Following vacuum filtration $(0.45 \mu \mathrm{m})$ of $100 \mathrm{~mL}$ of runoff sample, filtrate was analyzed using the salicylate-hypochlorite method for $\mathrm{NH}_{4}-\mathrm{N}$ (Crooke and Simpson, 1971) and the Griess-Ilosvay method (Keeney and Nelson, 1982) for $\mathrm{NO}_{3}-\mathrm{N}$ and any nitrite $\mathrm{N}\left(\mathrm{NO}_{2}-\mathrm{N}\right)$ following reduction of $\mathrm{NO}_{3}{ }^{-}$to $\mathrm{NO}_{2}{ }^{-}$with a Cd column. Total Kjeldahl $\mathrm{N}$ was determined similarly following Kjeldahl digestion of an unfiltered sample according to USEPA Method 351.2 (USEPA, 
1993). Unfiltered soil water extracts from lysimeters were analyzed for $\mathrm{NO}_{3}-\mathrm{N}$ and $\mathrm{NH}_{4}-\mathrm{N}$.

At each rain event, runoff samples collected at 5-min intervals from each plot represented point estimates of concentrations and were plotted against cumulative runoff volume for that specific rain event and plot. The points were joined with straight lines and the area under the plot was integrated according to the trapezoid rule using the PROC EXPAND procedure (SAS Institute, 1994). This method determined the cumulative mass of $\mathrm{N}$ exported at each collection time, the main focus here being $\mathrm{N}$ export during $30 \mathrm{~min}$ of runoff.

The effects of cover, site (a combination of slope and soil differences), and month of rain event on $\mathrm{NO}_{3}-\mathrm{N}, \mathrm{NH}_{4}-\mathrm{N}$, and $\mathrm{TN}$ mass export and concentrations were determined using the PROC GLM procedure (SAS Institute, 1994). Means were separated using Fisher's least significant difference. Unless otherwise noted, all differences were considered to be significant at $P<0.05$.

\section{RESULTS AND DISCUSSION}

\section{Cover}

Target ground cover levels of $0,45,70$, and $95 \%$ were established at the soil surface. As canopy cover measurements often differed from the established level of ground cover (basal cover), $45 \%$ ground cover will be considered as low cover, $70 \%$ ground cover will be considered as medium cover, and $95 \%$ ground cover will be considered as high cover, with the $0 \%$, compacted treatment referred to as bare ground to facilitate discussion of ground cover treatments. Actual canopy cover (note: not basal cover) varied across the five rain events (Table 1). Mean canopy cover at low cover ranged from $63 \%$ in April to $78 \%$ in October, canopy cover at medium cover ranged from $76 \%$ in April to $83 \%$ in October, and canopy cover at high cover ranged from $98 \%$ in April to $83 \%$ in October. The changes observed in canopy cover levels emphasize the difficulty in maintaining desired levels of cover throughout the growing season.

Mean canopy cover differed at each level of established ground cover for every rainfall event, except during October. In October, no statistical difference in mean canopy cover was observed between low, medium, and high ground cover levels. As the season progressed, thicker forage growth in grid rectangles that were selected to include live forage likely increased canopy cover values of the low and medium cover levels through some spreading into adjacent bare grid rectangles. This is important to note, as this shielding effect could also shield soil in adjacent blank grid rectangles from raindrop impact.

Levels of cover are also reflected in the amount of $\mathrm{N}$ uptake by forages between each rainfall event (Table 3 ). As expected, forages on high cover plots generally removed the greatest amount of $\mathrm{N}$, though only significantly more than medium cover in the growth period between the September and October events. Total forage N-uptake for all harvests following the first application of feces and urine in May did not differ at low, medium, or high cover. This is likely due to a large proportion of $\mathrm{N}$ uptake occurring during the summer months between the June and September rain events, a
Table 3. Mean total nitrogen $(\mathbf{N})$ removed at forage harvest.

\begin{tabular}{|c|c|c|c|c|c|}
\hline \multirow[b]{3}{*}{ Cover } & \multicolumn{5}{|c|}{ Total N removed } \\
\hline & \multicolumn{5}{|c|}{ Forage growth period } \\
\hline & $\begin{array}{c}\text { Apr. to } \\
\text { May }\end{array}$ & $\begin{array}{c}\text { May to } \\
\text { June }\end{array}$ & $\begin{array}{c}\text { June to } \\
\text { Sept. }\end{array}$ & $\begin{array}{l}\text { Sept. to } \\
\text { Oct. }\end{array}$ & $\begin{array}{c}\text { Post } \\
\text { application } \\
\text { total } \ddagger\end{array}$ \\
\hline \multirow{5}{*}{$\begin{array}{l}\text { Bare } \\
\text { Low } \\
\text { Medium } \\
\text { High }\end{array}$} & & & $-k g N$ ha & & \\
\hline & $0.0 \mathrm{~b} \dagger$ & $0.0 \mathrm{c}$ & $34.0 b$ & $0.0 \mathrm{c}$ & $34.0 \mathrm{~b}$ \\
\hline & 3.7ab & $7.0 \mathrm{~b}$ & 76.4a & $4.2 \mathrm{~b}$ & 87.6a \\
\hline & 7.6a & $10.4 a$ & 78.4a & $6.2 \mathrm{~b}$ & $95.0 \mathrm{a}$ \\
\hline & $5.7 \mathbf{a}$ & 11.8a & 78.4a & $10.4 a$ & $100.6 a$ \\
\hline
\end{tabular}

$\dagger$ Means in the same column followed by the same letter are not significantly different $(P>0.05)$.

$¥$ Total $\mathbf{N}$ removed for experiment, following the first application of feces and urine at the May rain event.

period during which maintaining experimental cover levels was difficult. Following feces and urine applications (total $\mathrm{N}$ application of $\sim 200 \mathrm{~kg} \mathrm{~N} \mathrm{ha}^{-1}$ ), forages at low, medium, and high cover levels removed a total of $\sim 100 \mathrm{~kg} \mathrm{~N} \mathrm{ha}^{-1}$ over all forage harvests.

\section{Rainfall Rate and Distribution}

At simulated rain events, a rainfall rate of $70 \mathrm{~mm} \mathrm{~h}^{-1}$ was the target output for each rainfall simulator. However, rainfall rate determined from rain gauges at the plots recorded a higher mean rainfall rate of $102 \mathrm{~mm} \mathrm{~h}^{-1}$ with a standard deviation of $15 \mathrm{~mm} \mathrm{~h}^{-1}$. Mean rainfall rate and rainfall rate recorded adjacent to feces and urine deposits were included as covariates in initial statistical models to account for any variation, but were not significantly related to cumulative export of $\mathrm{NO}_{3}-\mathrm{N}$, $\mathrm{NH}_{4}-\mathrm{N}$, and TN during $30 \mathrm{~min}$ of runoff and were not included in subsequent statistical analysis. As the same simulator was used on all plots within a block, the block effect in the statistical model helps account for any differences among the rainfall simulators.

\section{Soil Inorganic Nitrogen}

Soil inorganic $\mathrm{N}$ on plots at low, medium, and high cover was generally consistent throughout the season, averaging $16 \mathrm{mg} \mathrm{N} \mathrm{kg}^{-1}$ (Table 4). However, at bare ground, mean soil inorganic $\mathrm{N}$ varied seasonally. At the baseline event, there was no difference between soil $\mathrm{N}$ levels at bare ground and the other levels of cover. Before the first feces and urine application in May, mean soil inorganic $\mathrm{N}$ was greatest from bare ground and $45 \%$

Table 4. Mean soil inorganic nitrogen $(N)$ levels at each cover level and rain event; soil samples taken at 0 - to $5-\mathrm{cm}$ depth before rain events.

\begin{tabular}{lccccc}
\hline & \multicolumn{5}{c}{ Soil inorganic N } \\
\cline { 2 - 6 } Cover & May & June & Sept. & Oct. \\
\cline { 2 - 6 } & Base & \multicolumn{5}{c}{ main event } \\
Bare & 19.0 & $17.0 \mathrm{~N} \dagger$ & $\mathbf{7 2 . 4 a}$ & $\mathbf{5 5 . 0 a}$ & $\mathbf{5 2 . 8 a}$ \\
Low & $\mathbf{1 7 . 3}$ & $\mathbf{9 . 5 4 b}$ & $\mathbf{1 5 . 7 b}$ & $\mathbf{1 5 . 9 b}$ & $\mathbf{1 3 . 2 b}$ \\
Medium & $\mathbf{1 8 . 0}$ & $\mathbf{1 0 . 9 b}$ & $\mathbf{1 9 . 4 b}$ & $\mathbf{1 6 . 0 b}$ & $\mathbf{1 5 . 8 b}$ \\
High & $\mathbf{1 7 . 8}$ & $\mathbf{7 . 5 0 b}$ & $\mathbf{2 3 . 0 b}$ & $\mathbf{1 6 . 1 b}$ & $\mathbf{1 6 . 4 b}$ \\
\hline
\end{tabular}

$\uparrow$ Means in the same column followed by the same letter or no letters are not significantly different $(P>0.05)$. 
less at the other levels of cover. This difference was more evident for the June, September, and October rain events when soil $\mathrm{N}$ averaged $60 \mathrm{mg} \mathrm{N} \mathrm{kg}{ }^{-1}$ at bare ground compared with $17 \mathrm{mg} \mathrm{N} \mathrm{kg}^{-1}$ at low, medium, and high cover levels. This was expected, as the forage in plots with any level of vegetative cover removed $\mathrm{N}$ for growth, leaving less extractable $\mathrm{N}$ in the soil on vegetated plots compared with bare ground plots.

\section{Runoff Nitrate Nitrogen}

Both cover and rain event were significantly related to cumulative $\mathrm{NO}_{3}-\mathrm{N}$ export during $30 \mathrm{~min}$ of runoff (Table 5). There was also a significant interaction between cover and rain event. Due to interaction, the effect of ground cover on mean $\mathrm{NO}_{3}-\mathrm{N}$ export during 30 min of runoff was examined at each rain event, as well as with all rain events combined.

While not consistent at each rain event, mean $\mathrm{NO}_{3}-\mathrm{N}$ export was generally greater from bare ground than at low, medium, and high cover levels (Fig. 1). This was not the case for the September rain event, however, when there was relatively small export of $\mathrm{NO}_{3}-\mathrm{N}$ from bare ground plots during that rain event. Considering the sum of all rain events, bare ground produced the greatest $\mathrm{NO}_{3}-\mathrm{N}$ export, but only $\sim 1 \mathrm{~kg} \mathrm{~N} \mathrm{ha}^{-1} \mathrm{yr}^{-1}$ greater than the export observed from low cover. Additionally, mean export at medium cover was less than that at low cover. However, neither low nor medium cover differed from high cover. These data suggest that low, medium, and high cover all provide greater protection from $\mathrm{NO}_{3}-\mathrm{N}$ losses than bare ground, but also that $\mathrm{NO}_{3}-\mathrm{N}$ export from bare ground may be more modest than one might expect. The differences among low, medium, and high cover levels are less clear, as the data suggest that low cover ( $45 \%$ basal cover) may reduce $\mathrm{NO}_{3}-\mathrm{N}$ export as well as greater cover levels. Considering that actual canopy cover values for low cover were $\sim 70 \%$ in this study, examining lower levels of canopy cover in future studies may help determine a threshold value of canopy cover above which $\mathrm{NO}_{3}-\mathrm{N}$ in runoff is reduced at

Table 5. ANOVA: Cumulative total runoff parameters during $30 \mathrm{~min}$ of runoff.

\begin{tabular}{|c|c|c|c|c|}
\hline \multirow[b]{2}{*}{ Source } & \multirow[b]{2}{*}{$\mathbf{D F} \dagger$} & \multicolumn{3}{|c|}{$P$ values } \\
\hline & & $\mathbf{N O}_{3}-\mathbf{N}$ & $\mathbf{N H}_{4}-\mathbf{N}$ & $\mathbf{T N}$ \\
\hline Model & 87 & $* * *$ & $* * *$ & $* * *$ \\
\hline \multicolumn{5}{|l|}{ Hypothesis tests } \\
\hline Site & 1 & NS§ & NS & NS \\
\hline Block (site) & 6 & $* * *$ & NS & $* *$ \\
\hline Cover & 3 & $*$ & $* * *$ & $* * *$ \\
\hline Cover $\times$ site & 3 & NS & NS & II \\
\hline Cover $\times$ block (site) & 18 & NS & NS & NS \\
\hline Rain event & 4 & $*$ & $* * *$ & $* * *$ \\
\hline Cover $\times$ event & 12 & $*$ & $* * *$ & $* * *$ \\
\hline Site $\times$ event & 4 & NS & $*$ & NS \\
\hline Block (site) $\times$ event & 24 & $* *$ & NS & NS \\
\hline Cover $\times$ event $\times$ site & 12 & NS & NS & NS \\
\hline Residual & 72 & & & \\
\hline Total & 159 & & & \\
\hline
\end{tabular}

$*$, **, ***, significant at $\boldsymbol{P}<0.05,0.01$, and 0.001 , respectively.

$\dagger$ DF, degrees of freedom.

$\$ T N$, total nitrogen.

$\S \mathrm{NS}$, not significant.

I $P<0.1$.

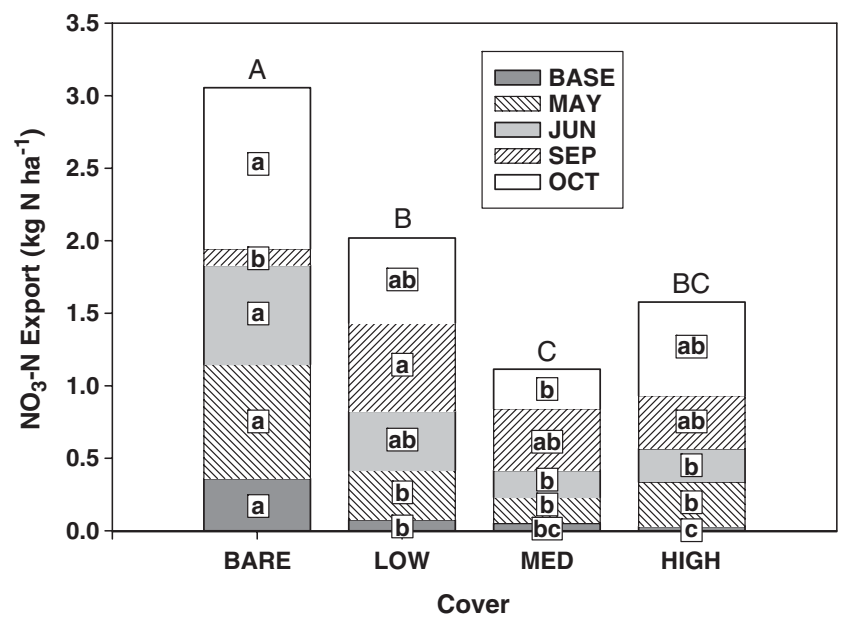

Fig. 1. Mean cumulative nitrate nitrogen $\left(\mathrm{NO}_{3}-\mathrm{N}\right)$ export during $30 \mathrm{~min}$ of runoff, as affected by cover (means within each rain event with the same lowercase letter are not significantly different, $P>0.05$; uppercase letters indicate significant differences among the combined means of all rain events; diagonal sections indicate application of cattle feces and urine).

an equivalent level as full ground cover. In our study, $\mathrm{NO}_{3}-\mathrm{N}$ export was not as low as that reported by Edwards et al. (2000b), where export in runoff from applied beef cattle manures was $<0.03 \mathrm{~kg} \mathrm{~N} \mathrm{ha}^{-1}$ under full cover conditions.

To better assess the effect of rain event, $\mathrm{NO}_{3}-\mathrm{N}$ export was examined at each level of cover as well as the sum for all cover levels at each rain event (Fig. 2). While these data have already been examined at each level of cover, it is interesting to note the large export of $\mathrm{NO}_{3}-\mathrm{N}$ in October for the sum of all cover levels, whereas export did not differ in May, June, or September. Low export at bare ground in September, perhaps due to the compaction procedure breaking the soil surface during this dry period of the year and allowing for greater infiltration, tends to mask the otherwise high export in that month. Several studies of $\mathrm{NO}_{3}-\mathrm{N}$ leaching from manures have similarly shown relatively high $\mathrm{NO}_{3}-\mathrm{N}$

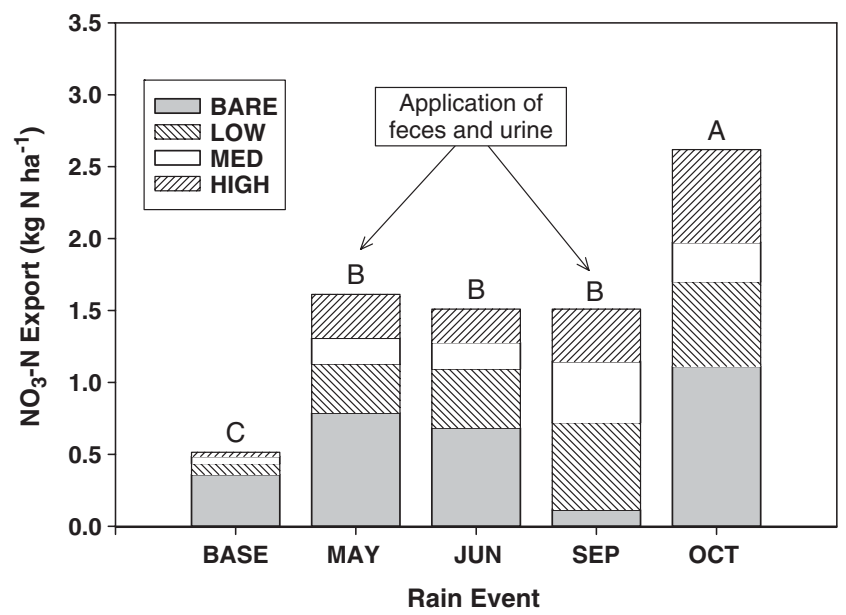

Fig. 2. Mean cumulative nitrate nitrogen $\left(\mathrm{NO}_{3}-\mathrm{N}\right)$ export during $30 \mathrm{~min}$ of runoff, as affected by rain event (bars with the same letter are not significantly different in the combined mean of all rain events, $P>0.05)$. 
export occurring during the fall season (Stout et al., 1998; Decau et al., 2003; van Es et al., 2006). The general trend of increased export in the fall months may be explained by nitrification of $\mathrm{NH}_{4}-\mathrm{N}$ and mineralization of organic $\mathrm{N}$, as well as the buildup of fecal material on the plots. The $\mathrm{N}$ that remained in above-ground fecal material before fresh application at the September rain event ranged from 15 to $25 \mathrm{~kg} \mathrm{~N}^{-1}$, compared with the initial $\sim 30 \mathrm{~kg} \mathrm{~N} \mathrm{ha}^{-1}$ added in fresh feces at the May rain event. However, previously applied feces may have decomposed more rapidly in an actual pasture setting with cattle hoof action and more frequent small rain events, in contrast to the conditions in this study. Results reported here do contrast somewhat with those of McDowell et al. (2006) who reported that $\mathrm{NO}_{3}-\mathrm{N}$ in runoff was generally unaffected by the application of dairy cattle manures at a similar rate, where pasture ground cover was reported to be $95 \%$.

\section{Runoff Ammonium Nitrogen}

Analysis of cumulative $\mathrm{NH}_{4}-\mathrm{N}$ export during 30 min of runoff indicated significance of cover $(P<0.001)$ and rain event $(P<0.001)$ (Table 5). Interactions were observed between cover and rain event $(P<0.001)$ and between site and rain event. Due to the significant interaction effect, mean $\mathrm{NH}_{4}-\mathrm{N}$ export in relation to ground cover was examined at each rain event.

High $\mathrm{NH}_{4}-\mathrm{N}$ export associated with rain events in May and September, which included application of feces and urine may explain the interaction effect (Table 6). At these events, there was a greater export of $\mathrm{NH}_{4}-\mathrm{N}$ at bare ground than at all other cover levels, which did not differ. At other rain events, mean $\mathrm{NH}_{4}-\mathrm{N}$ export during 30 min of runoff was minimal $\left(<0.02 \mathrm{~kg} \mathrm{~N} \mathrm{ha}^{-1}\right)$, and few differences were observed between any of the cover levels. The loss of $\mathrm{NH}_{4}-\mathrm{N}$ was at least 65 -fold greater when rainfall occurred immediately after deposition of feces and urine to bare ground, as compared with 1 mo afterward. Additionally, bare ground contributed at least five times the export of $\mathrm{NH}_{4}-\mathrm{N}$ during those high export events compared with other levels of cover.

The greater $\mathrm{NH}_{4}-\mathrm{N}$ export following feces and urine application in this experiment was consistent with the findings of Trlica et al. (2000), who reported $\mathrm{NH}_{4}-\mathrm{N}$ concentrations of runoff following grazing in northern Colorado to be 10 -fold greater than ungrazed plots and Elliott and Carlson (2004) who reported a 17-fold in-

Table 6. Mean cumulative ammonium nitrogen $\left(\mathrm{NH}_{4}-\mathrm{N}\right)$ export during $30 \mathrm{~min}$ of runoff.

\begin{tabular}{llcccc}
\hline & \multicolumn{5}{c}{$\mathrm{NH}_{4}-\mathrm{N}$ export } \\
\cline { 2 - 6 } Cover & \multicolumn{5}{c}{ Rain event } \\
\cline { 2 - 6 } & Base & May & June & Sept. & Oct. \\
\cline { 2 - 6 } Bare & \multicolumn{5}{c}{ kg N ha $^{-1}$} \\
Low & $\mathbf{0 . 0 0 0 b \dagger}$ & $\mathbf{1 . 2 5 4 a}$ & $\mathbf{0 . 0 1 6}$ & $\mathbf{7 . 8 9 8 a}$ & $\mathbf{0 . 0 0 5 a}$ \\
Medium & $\mathbf{0 . 0 1 6 a}$ & $\mathbf{0 . 0 5 8 b}$ & $\mathbf{0 . 0 0 7}$ & $\mathbf{0 . 7 2 2 b}$ & $\mathbf{0 . 0 0 1 b}$ \\
High & $\mathbf{0 . 0 0 9 a b}$ & $\mathbf{0 . 0 6 2 b}$ & $\mathbf{0 . 0 1 3}$ & $\mathbf{0 . 0 5 7 b}$ & $\mathbf{0 . 0 0 3 a b}$ \\
\hline
\end{tabular}

$\dagger$ Means in the same column followed by the same letter or no letters are not significantly different $(P>0.05)$. crease in $\mathrm{NH}_{4}-\mathrm{N}$ concentrations following summer grazing by sheep. The pattern of lower export of $\mathrm{NH}_{4}-$ $\mathrm{N}$ during rain events 1 mo after manure application was similar to the findings of Franklin et al. (2006), who reported $\mathrm{NH}_{4}-\mathrm{N}$ losses 1 mo after poultry litter application to be only $1.4 \%$ of losses seen immediately after litter application in a Piedmont environment. Pierson et al. (2001) also reported a rapid decrease in $\mathrm{NH}_{4}-\mathrm{N}$ runoff concentrations following application of poultry litter in central Georgia, as did McDowell et al. (2006) following dairy cattle manure application in Australia. Nitrification of $\mathrm{NH}_{4}-\mathrm{N}$ to $\mathrm{NO}_{3}-\mathrm{N}$ may be partly responsible for the response of $\mathrm{NH}_{4}-\mathrm{N}$ mass export over rain events, as export of $\mathrm{NO}_{3}-\mathrm{N}$ did not decrease in the months following application of feces and urine in our study.

Of all 5-min sampling intervals up to $30 \mathrm{~min}$ after runoff initiation, concentration of $\mathrm{NH}_{4}-\mathrm{N}$ in runoff was significantly related to cover only at 0 (initial concentration), 5, and $10 \mathrm{~min}$ (data not shown). As runoff continued, mean concentrations at each level of cover did not differ. While this points to the importance of nutrients evolving from initial runoff, it should be noted that runoff volume at initiation of runoff was relatively low and thus the mass export of $\mathrm{NH}_{4}-\mathrm{N}$ may not necessarily have been greatly affected.

\section{Runoff Total Nitrogen}

The different responses of $\mathrm{NH}_{4}-\mathrm{N}$ and $\mathrm{NO}_{3}-\mathrm{N}$ with cover and rain event suggest that measures of TN export may provide a more complete understanding of $\mathrm{N}$ export. Total Kjeldahl nitrogen is a measure of organic $\mathrm{N}$ and $\mathrm{NH}_{4}-\mathrm{N}$ in runoff, and for a measure of $\mathrm{TN}$, export of TKN and $\mathrm{NO}_{3}-\mathrm{N}$ were summed. While $\mathrm{NH}_{4}-\mathrm{N}$ and $\mathrm{NO}_{3}-\mathrm{N}$ are readily available for uptake by plants and other aquatic organisms, organic forms of $\mathrm{N}$ are less available but are critical to developing a more complete understanding of $\mathrm{N}$ exports from pastured systems. Cumulative export of TN during 30 min of runoff was significantly related to both cover $(P<0.001)$ and rain event $(P<$ $0.001)$, but not to site. In addition, there was an interaction between cover and rain event $(P<0.001)$ (Table 5).

Due to the interaction, the impact of cover on mean TN export during $30 \mathrm{~min}$ of runoff was examined at each rain event (Fig. 3). At each rain event except June, mean TN export was at least sevenfold greater from bare ground plots than at low, medium, and high cover levels, which did not differ from each other. Additionally, the sum of TN export over all rain events was 5- to 10-fold greater from bare ground plots than other levels of cover. The lack of differences among cover levels is somewhat inconsistent with the findings of Elliott and Carlson (2004) who reported a linear relationship among different levels of cover (all greater than 89\%) and runoff TKN concentrations. This may have been due to the steeper slopes of 20 to $35 \%$ compared with slopes of 10 and $20 \%$ in our study.

The relatively low TN export in June is consistent with low runoff volume and sediment export during the June rain event as reported in a companion paper (Butler et al., 2006). Studies in South Carolina and Arkansas 


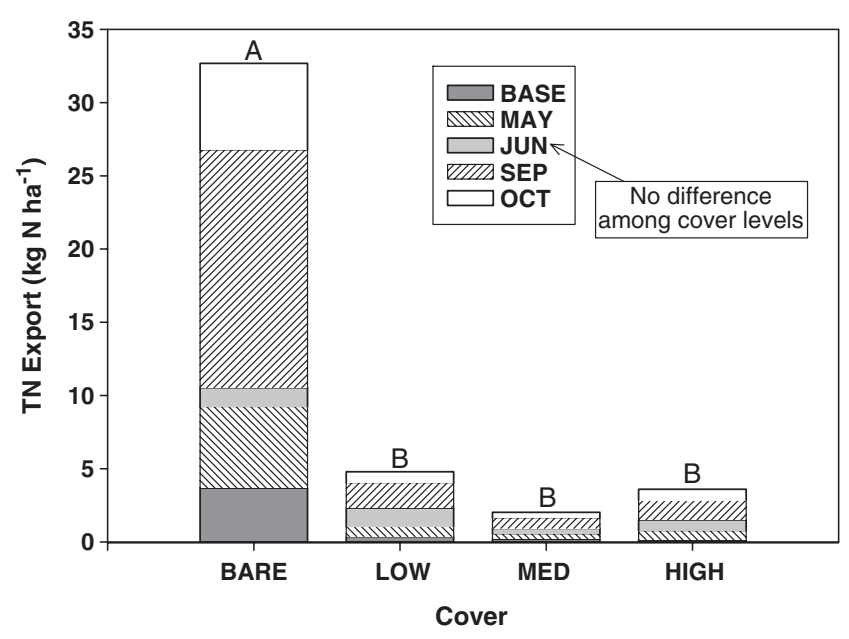

Fig. 3. Mean cumulative total nitrogen (TN) export during $30 \mathrm{~min}$ of runoff, as affected by cover (bars with the same letter are not significantly different in the combined mean of all rain events, $P>$ 0.05; means within each rain event had the same relationships as the combined mean except in June; diagonal sections indicate application of cattle feces and urine).

have reported substantially reduced TKN when rainfall occurred 1 to 2 wk after manure application (McLeod and Hegg, 1984; Sauer et al., 1999), but those results may have been partly due to decreased levels of $\mathrm{NH}_{4}-\mathrm{N}$ in runoff from subsequent rains after manure application. If $\mathrm{NO}_{3}-\mathrm{N}$ were included to give a measure of $\mathrm{TN}$, the relationship may have differed. In our study, $\mathrm{NO}_{3}-\mathrm{N}$ did not decrease as much as $\mathrm{NH}_{4}-\mathrm{N}$ in the month following initial manure and urine application, likely due to nitrification of $\mathrm{NH}_{4}-\mathrm{N}$ and mineralization of organic $\mathrm{N}$ to $\mathrm{NO}_{3}-\mathrm{N}$ during the 1-mo interval between rain events.

Concentration of TN in runoff was also examined, and as with other nutrients, the greatest difference in concentration was observed at the initial runoff sampling. Mean concentration of TN from bare ground plots was $93.0 \mathrm{mg} \mathrm{N} \mathrm{L}^{-1}$, which was 6- to 12 -fold greater than the concentration at all other cover levels. Initial runoff concentration averaged $14.5 \mathrm{mg} \mathrm{N} \mathrm{L}^{-1}$ at low cover, $7.44 \mathrm{mg} \mathrm{N} \mathrm{L}^{-1}$ at medium cover, and $9.08 \mathrm{mg} \mathrm{N} \mathrm{L}^{-1}$ at full cover which did not differ from each other.

\section{Soil Water Extracts}

Difficulties were encountered in obtaining soil water extracts due to low ambient soil moisture levels and samples were collected only at September and October rain events. There was no difference in $\mathrm{NO}_{3}-\mathrm{N}$ or $\mathrm{NH}_{4}-\mathrm{N}$ concentration means by either cover or rain event, with analysis limited due to missing values that reduced degrees of freedom and statistical power. However, some large concentrations of $\mathrm{NO}_{3}-\mathrm{N}$ (up to $22 \mathrm{mg} \mathrm{L}^{-1}$ ) were recorded in extracts from the October event (data not shown), suggesting that leaching losses may have accounted for a large portion of applied N. In central Pennsylvania, Stout et al. (1998) reported that $25 \%$ of applied urine $\mathrm{N}$ was lost by leaching, whereas leaching from applied feces was negligible. Results obtained from soil water extracts in our study were consistent with the high mass export of $\mathrm{NO}_{3}-\mathrm{N}$ reported in surface runoff during the October rain event as well as other studies which suggest the greatest risk of $\mathrm{NO}_{3}-\mathrm{N}$ leaching is during the autumn (Stout et al., 1998; Decau et al., 2003; van Es et al., 2006).

\section{Total Nitrogen Balance}

In view of the mean annual export of $<5 \mathrm{~kg} \mathrm{TN} \mathrm{ha}^{-1}$ in runoff from plots at low, medium, and high cover levels (Fig. 3), it is important to consider the fate of the more than $200 \mathrm{~kg} \mathrm{~N}^{-1}$ applied in feces in urine (Table 2). Though this study was not designed to evaluate all possible pathways of $\mathrm{N}$ export or sequestration, levels of inorganic soil $\mathrm{N}$, total soil $\mathrm{N}$, forage $\mathrm{N}$ uptake, $\mathrm{N}$ concentrations of soil water extracts, and the amount of $\mathrm{N}$ remaining in above-ground fecal material were examined. For plots at low, medium, and high cover, there was no appreciable increase in either inorganic (Table 4) or total soil $\mathrm{N}$ levels (data not shown) through the course of the study. Following the application of feces and urine to plots at low, medium, or high cover, forage growth utilized 85 to $100 \mathrm{~kg} \mathrm{~N}^{-1}$ (Table 3), nearly $50 \%$ of total $\mathrm{N}$ applied. Given that forage growth was limited on bare plots, a much greater percentage of $\mathrm{N}$ was exported in runoff and present in the soil as inorganic $\mathrm{N}$, as discussed in previous sections of this paper.

At the September event, the amount of $\mathrm{N}$ remaining in recognizable aboveground fecal material ranged from 15 to $25 \mathrm{~kg} \mathrm{~N} \mathrm{ha}^{-1}$, suggesting that a large portion of total $\mathrm{N}$ applied in the feces $\left(\sim 30 \mathrm{~kg} \mathrm{~N} \mathrm{ha}^{-1}\right.$ at both May and September events) remained on the plot surface during the course of this 7-mo study. Considering rainfall simulations were conducted immediately after application of feces and acidified urine, volatilization losses of $\mathrm{N}$ were likely minimal, though not quantified as part of this study. As mentioned in the previous section, considering the relatively high concentration of $\mathrm{N}$ present in soil water extracts, $\mathrm{N}$ leaching was likely the major pathway for export of $\mathrm{N}$ not accounted for in runoff collection, forage harvests, soil samples, and recoverable fecal material.

\section{CONCLUSIONS}

Averaged across all rain events and sites, the greatest export of $\mathrm{NO}_{3}-\mathrm{N}, \mathrm{NH}_{4}-\mathrm{N}$, and $\mathrm{TN}$ was observed from plots at bare ground, strongly reinforcing the importance of elimination and prevention of lounging areas in riparian areas. While some differences were noted among low, medium, and high cover, $\mathrm{N}$ export at high cover was not significantly less than $\mathrm{N}$ export at low cover. Considering the large magnitude of TN losses at bare ground compared with all other levels of cover (over fivefold greater), results suggest that complete canopy cover is not essential to limit $\mathrm{N}$ export from riparian pasture. It may be possible to utilize forages in and near riparian areas as part of a rotational grazing system provided that at least $45 \%$ basal cover or $70 \%$ canopy cover are maintained. Recognizing the difficulty in creating and maintaining desired ground cover levels for research plots, future work examining levels 
of cover lower than those used in this study may provide useful information to those managing livestock in and near riparian areas. A range of forage species could also be examined to determine $\mathrm{N}$ export from forages with different growth habits and seasonal distribution of growth.

As $\mathrm{N}$ exports varied according to timing of rainfall in relation with feces and urine application, timing of grazing in relation to expected runoff events is likely a critical aspect of grazing management in riparian areas. Riparian and other environmentally sensitive areas may be best utilized for short time periods during drier seasons of the year, allowing nutrients to be used by forages or immobilized in the soil before rain events producing heavy runoff are likely to occur.

\section{ACKNOWLEDGMENTS}

Special thanks are extended to the following individuals for invaluable help with the completion of this project: Elizabeth Barton, Dr. Cavell Brownie, Sharon Freeman, Dr. Jerry Huntington, Justin Garrett, Heather Glennon, Ricardo Goulart, Everett Gupton, T.J. Holliday, Brenna Houchins, Aaron Maye, Nathan McClintock, Izzy Menius, Guillermo Ramirez, April Shaeffer, Lucie Smith, Dr. Bir Thapa, Pete Thompson, and Mike Weeks.

\section{REFERENCES}

Alderfer, R.B., and R.R. Robinson. 1947. Runoff from pastures in relation to grazing intensity and soil compaction. J. Am. Soc. Agron. 39:948-958.

Butler, D.M., D.H. Franklin, N.N. Ranells, M.H. Poore, and J.T. Green, Jr. 2006. Ground cover impacts on sediment and phosphorus export from manured riparian pasture. J. Environ. Qual. 35:2178-2185.

Carpenter, S.R., N.F. Caraco, D.L. Correll, R.W. Howarth, A.N. Sharpley, and V.H. Smith. 1998. Nonpoint pollution of surface waters with phosphorus and nitrogen. Ecol. Appl. 8:559-568.

Clary, W.P. 1995. Vegetation and soil responses to grazing simulation on riparian meadows. J. Range Manage. 48:18-25.

Costin, A.B. 1980. Runoff and soil losses from an improved pasture at Ginninderra, Southern Tablelands, New South Wales. Aust. J. Agric. Res. 31:533-546.

Crooke, W.M., and W.E. Simpson. 1971. Determination of ammonium on Kjeldahl digests of crops by an automated procedure. J. Sci. Food Agric. 22:9-10.

Cunniff, P. (ed.). 1995. Official methods of analysis of AOAC International, Vol. I. AOAC International, Gaithersburg, MD.

Dadkhah, M., and G.F. Gifford. 1980. Influence of vegetation, rock cover, and trampling on infiltration rates and sediment production. Water Resour. Bull. 16:979-986.

Decau, M.L., J.C. Simon, and A. Jacquet. 2003. Fate of urine nitrogen in three soils throughout a grazing season. J. Environ. Qual. 32: 1405-1413.

Edwards, D.R., T.K. Hutchens, R.W. Rhodes, B.T. Larson, and L. Dunn. 2000a. Quality of runoff from plots with simulated grazing. J. Am. Water Resour. Assoc. 36:1063-1073.

Edwards, D.R., B.T. Larson, and T.T. Lim. 2000b. Runoff nutrient and fecal coliform content from cattle manure application to fescue plots. J. Am. Water Resour. Assoc. 36:711-721.

Elliott, A.H., and W.T. Carlson. 2004. Effects of sheep grazing episodes on sediment and nutrient loss in overland flow. Aust. J. Soil Res. 42:213-220.

Franklin, D.H., M.L. Cabrera, and V.H. Calvert. 2006. Fertilizer source and soil aeration effects on runoff volume and quality. Soil Sci. Soc. Am. J. 70:84-89.
Haynes, R.J., and P.H. Williams. 1993. Nutrient cycling and soil fertility in the grazed pasture ecosystem. Adv. Agron. 49:119-199.

Hershfield, D.M. 1961. Rainfall frequency atlas of the United States for durations from 30 minutes to 24 hours and return periods from 1 to 100 years. Weather Bureau Technical Paper No. 40. U.S. Weather Bureau, Washington, DC.

Keeney, D.R., and D.W. Nelson. 1982. Nitrogen-Inorganic forms. p. 643-689. In A.L. Page et al. (ed.) Methods of soil analysis. Part 2, 2nd ed. Agron. Monogr. 9. ASA, CSSA, and SSSA, Madison, WI.

Kleinman, P.J.A., A.N. Sharpley, A.M. Wolf, D.B. Beegle, and P.A. Moore, Jr. 2002. Measuring water-extractable phosphorus in manure as an indicator of phosphorus in runoff. Soil Sci. Soc. Am. J. 66:2009-2015.

Kohn, R.A., M.M. Dinneen, and E. Russek-Cohen. 2005. Using blood urea nitrogen to predict nitrogen excretion and efficiency of nitrogen utilization in cattle, sheep, goats, horses, pigs, and rats. J. Anim. Sci. 83:879-889.

Laflen, J.M., M. Amemiya, and E.A. Hintz. 1981. Measuring crop residue cover. J. Soil Water Conserv. 6:341-343.

Lang, R.D. 1979. The effect of ground cover on surface runoff from experimental plots. J. Soil Conserv. Serv. NS. W. 35:108-114.

Loch, R.J. 2000. Effects of vegetation cover on runoff and erosion under simulated rain and overland flow on a rehabilitated site on the Meandu Mine, Tarong, Queensland. Aust. J. Soil Res. 38: 299-312.

McDowell, R.W., R.W. Muirhead, and R.M. Monaghan. 2006. Nutrient, sediment, and bacterial losses in overland flow from pasture and cropping soils following cattle dung deposition. Commun. Soil Sci. Plant Anal. 37:93-108.

McGinty, W.A., F.E. Smeins, and L.B. Merrill. 1979. Influence of soil, vegetation, and grazing management on infiltration rate and sediment production of Edwards Plateau rangeland. J. Range Manage. 32:33-37.

McLeod, R.V., and R.O. Hegg. 1984. Pasture runoff quality from application of inorganic and organic nitrogen sources. J. Environ. Qual. 13:122-126.

Mwendera, E.J., and M.A.M. Saleem. 1997. Infiltration rates, surface runoff, and soil loss as influenced by grazing pressure in the Ethiopian highlands. Soil Use Manage. 13:29-35.

Pierson, S.T., M.L. Cabrera, G.K. Evanylo, H.A. Kuykendall, C.S. Hoveland, M.A. McCann, and L.T. West. 2001. Phosphorus and ammonium concentrations in surface runoff from grasslands fertilized with broiler litter. J. Environ. Qual. 30:1784-1789.

SAS Institute. 1994. SAS/STAT User's guide, Version 8. 2nd ed. SAS, Cary, NC.

Sauer, T.J., T.C. Daniel, P.A. Moore, Jr., K.P. Coffey, D.J. Nichols, and C.P. West. 1999. Poultry litter and grazing animal waste effects on runoff water quality. J. Environ. Qual. 28:860-865.

Stout, W.L., W.J. Gburek, R.R. Schanbel, G.J. Folmar, and S.R. Weaver. 1998. Soil-climate effects on nitrate leaching from cattle excreta. J. Environ. Qual. 27:992-998.

Trlica, M.J., E.A. Nibarger, W.C. Leininger, and G.W. Frasier. 2000. Runoff water quality from grazed and ungrazed montane riparian plots. p. 263-268. In AWRA Proc., Int. Conf. on Riparian Ecology and Management in Multi-Land Use Watersheds, Portland, OR. 28-31 Aug. 2000. Am. Water Resour. Assoc., Middleburg, VA.

USDA. 2002. Census of Agriculture. National Agricultural Statistics Service. USDA, Washington, DC.

USEPA. 1993. Determination of total Kjeldahl nitrogen by semiautomated colorimetry. p. 449-464. In J.W. O'Dell (ed.) Methods for the determination of metals and inorganic chemicals in environmental samples. Noyes, Cincinnati, $\mathrm{OH}$.

van Es, H.M., J.M. Sogbedji, and R.M. Schindelbeck. 2006. Effect of manure application timing, crop, and soil type on nitrate leaching. J. Environ. Qual. 35:670-679.

White, R.K., L.B. Owens, R.W. VanKeuren, and W.M. Edwards. 1980. Nonpoint surface runoff from cattle pasture-hydrology and nutrients. p. 293-313. In Livestock Waste: A Renewable Resource. Proceedings of the 4th International Symposium on Livestock Wastes, Amarillo, TX. 10-13 July 1980. Texas Tech Univ. Press, Lubbock. 